\title{
Effect of aqueous extracts of allelopathic plants on growth and biomass of wheat and weeds
}

Shazma Anwar ${ }^{1}$, Ashraf Hussain ${ }^{1}$, Muhammad Islam ${ }^{1 *}$, Zahid Hussain ${ }^{2}$, Ikramullah $^{1}$, Muhammad Numan Sohaib ${ }^{3}$ and Nadar Khan ${ }^{4}$

1. Department of Agronomy, The University of Agriculture, Peshawar-Pakistan

2. Department of Agronomy, Bacha Khan University, Charsadda-Pakistan

3. Department of Agronomy, Faculty of Crop and Food Sciences, PMAS-Arid Agriculture University RawalpindiPakistan

4. Department of Animal Nutrition, The University of Agriculture, Peshawar-Pakistan

*Corresponding author's email: islamswati439@yahoo.com

Citation

Shazma Anwar, Ashraf Hussain, Muhammad Islam, Zahid Hussain, Ikramullah, Muhammad Numan Sohaib and Nadar Khan. Effect of aqueous extracts of allelopathic plants on growth and biomass of wheat and weeds. Pure and Applied Biology. Vol. 6, Issue 4, pp1161-1170. http://dx.doi.org/10.19045/bspab.2017.600124

\begin{tabular}{llll}
\hline Received: 22/04/2017 & Revised: 23/08/2017 & Accepted: 11/09/2017 & Online First: 15/09/2017 \\
\hline \hline
\end{tabular}

\section{Abstract}

Weeds infestation is one of the yield limiting factors in Pakistan. Although chemical control of weeds is effective but may cause crop damage, resistance development of weeds and animal and human health problems. Therefore a field experiment was conducted at Agronomy Research Farm, The University of Agriculture, Peshawar-Pakistan to evaluate the effect of allelopathic plants water extract (Eucalyptus camaldulensis, Lantana camara, Parthenium hysterophorus and Sorghum halepense) and concentration of extracts (1:4, 1:5 and 1:6) on wheat and weed biomass during winter season 2015-16. The experiment was laid out in randomized complete block design using four replications. Plot size was $3 \mathrm{~m} \times 1.8 \mathrm{~m}$ having 6 rows $30 \mathrm{~cm}$ apart. One control plot in each replication was maintained. The plant water extracts in respective concentrations were sprayed one week after sowing with knapsack sprayer. The results indicated that plots that received Sorghum halepense water extract resulted in lower weed density $\left(43 \mathrm{~m}^{-}\right.$ $\left.{ }^{2}\right)$, fresh $\left(102.4 \mathrm{~g} \mathrm{~m}^{-2}\right)$ and dry $\left(19.9 \mathrm{~g} \mathrm{~m}^{-2}\right)$ weeds biomass. Similarly application of Sorghum halepense water extract in wheat crop increased emergence $\mathrm{m}^{-2}(89)$, leaf area tiller ${ }^{-1}\left(100.54 \mathrm{~cm}^{2}\right)$, leaf area index (3.0), plant height $(85.68 \mathrm{~cm})$, biological yield $\left(8717 \mathrm{~kg} \mathrm{ha}^{-1}\right)$ and harvest index $(38.34 \%)$. Among different plant water extracts concentration of 1:4 remarkably reduced weeds density $\left(35 \mathrm{~m}^{-2}\right)$, fresh $(74.6$ $\left.\mathrm{g} \mathrm{m}^{-2}\right)$ and dry $\left(15.8 \mathrm{~g} \mathrm{~m}^{-2}\right)$ weeds biomass, while application of different plant water extracts at 1:6 concentration produced maximum emergence $\mathrm{m}^{-2}(90)$, leaf area tiller-1 $\left(102.26 \mathrm{~cm}^{2}\right)$, leaf area index $(3.1)$, plant height $(89.03 \mathrm{~cm})$, biological yield $\left(9071 \mathrm{~kg} \mathrm{ha}^{-1}\right)$ and harvest index $(38.31 \%)$. Thus spray of Sorghum halepense water extract at 1:6 concentration performed better and is recommended for weeds suppression and enhancing wheat biomass in the study area.

Keywords: Allelopathic plants; Water extract; Weeds biomass; Wheat

Introduction

Wheat (Triticum aestivum L.) is grown worldwide for grain production and especially in Pakistan in winter season. It is rich source of protein [1]. In Pakistan wheat is planted on 1980 thousand hectare producing 25478 thousand tons. The average yield was $2775 \mathrm{~kg} \mathrm{ha}^{-1}$. The area under cultivation in Khyber Pakhtunkhwa was 636 thousand hectares producing 1150 thousand 
tons while average yield was $1807 \mathrm{~kg} \mathrm{ha}^{-1}$ [2].

In Pakistan low yield of wheat is due to high infestations of weeds besides other problems which is alarming for food security [3]. Though effective but the non-judicious use of artificial chemicals may result in damage of crop, resistance development of weeds and animal and human health problems are also associated [4]. An appropriate way of decreasing the application of synthetic chemicals is to use of natural chemicals such as allelopathic plants aqueous extracts which not only brings improvement in crop production but also protects the environment [5]. Allelopathy is inexpensive, natural, environment friendly approach and organic phenomena which can be practiced for weed management in the form of water extracts, crop rotation, mulching and intercropping [6].

Parthenium hysterophorus L. has allelopathic effect which considerably hinders the growth of many plant species in the environment [7]. The water extract of Eucalyptus camaldulensis limit growth of various kinds of weeds [8]. The eucalyptus water extract has inhibitory effect to root and shoot elongation of wheat crop [9]. Some researchers have so far worked on the incursion and allelopathic effects of Lantana camara on different agricultural crops [10]. Additionally, allelopathic effects of Lantana camara water extract on germination and seedling potency of crop, such as rice [10] and [11] and wheat [12] have been reported. Sorghum halepense aqueous extracts has potential to reduce biomass of weeds by 33$53 \%$ which enhanced the yield of wheat crop (7-14\%). The present research was conducted to evaluate the effect of aqueous extracts of different plants and their concentrations on the weeds suppression and wheat biomass under the agro climatic condition of Peshawar.

\section{Materials and methods}

The experiment was carried out at Agronomy Research Farm, The University of Agriculture Peshawar Pakistan during fall season 2015-16. The experiment was arranged in a randomized complete block design (RCBD) replicated four times. A plot size of $3 \mathrm{~m} \times 1.8 \mathrm{~m}$ having 6 rows $30 \mathrm{~cm}$ apart was used. The wheat variety Atta-Habib was sown on November 21, 2015 at the rate of $120 \mathrm{~kg} \mathrm{ha}^{-1}$. One control plot having no plant water extract and concentration in each replication was maintained. The different plants water extract and concentration were sprayed after one week of sowing with knapsack sprayer. Recommended rate of fertilizer (100-90 kg NP ha ${ }^{-1}$ ) was applied. All other agronomic practices were maintained uniformly.

The following factors along with their respective levels were studied. Allelopathic plant water extracts (E) as factor A including Eucalyptus camaldulensis, Lantana camara, Parthenium hysterophorus and Sorghum halepense. Concentration of extracts (C) $\mathrm{w} / \mathrm{v}$ as factor $\mathrm{B}$ having three levels i.e. $C_{1}=1: 4$ (1 kg plant material and 4 liters water), $\mathrm{C}_{2}=1: 5$ (1 kg plant material and 5 liters water) and $\mathrm{C}_{3}=1: 6(1 \mathrm{~kg}$ plant material and 6 liters water).

\section{Preparation of plant extracts}

The allelopathic plants namely Eucalyptus camaldulensis, Lantana camara, Parthenium hysterophorus and Sorghum halepense were harvested with the help of sickle. The plant materials were sun dried, chopped and soaked in water separately for 48 hours in the ratio of 1:4, 1:5 and 1:6 w/v. The material was filtered through muslin cloth to collect different concentrations of extracts.

Data were recorded for emergence $\mathrm{m}^{-2}$, weeds density and biomass, leaf area tiller ${ }^{-1}$, plant height, biological yield harvest index. Data on emergence $\mathrm{m}^{-2}$ was calculated in each plot by counting plants in the central 
three rows and was changed into emergence $\mathrm{m}^{-2}$ by using the formula:

Emergence $\mathrm{m}^{-2}=$ No. of seedling counted

$\mathrm{R}-\mathrm{R}$ distance $\mathrm{x}$ Row length $\mathrm{x}$ No. of rows The data on number of weeds was recorded at 60 days after sowing from randomly selected five sampling units in each plot with the help of iron frame of $0.5 \mathrm{~m} \times 0.5 \mathrm{~m}$ sample area. Weeds were counted and averaged. After that, weeds fresh biomass was recorded by digital balance and finally weeds dry biomass was noted after weeds were sun dried.

Area of leaf tiller-1 was deliberated by collecting leaves from arbitrarily selected five tillers from each plot at anthesis stage. The area of leaf was obtained from the product of average leaf length and average leaf width with correction factor (C.F) and total number of leaves which was then divided by the tillers number to find the leaf area tiller ${ }^{-1}$. The value of correction factor (C.F) used was 0.75 [13].

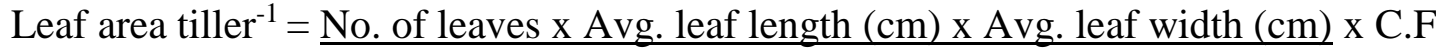

Number of tillers

Plant height data was recorded from randomly chosen ten plants in every plot from the base of plant to top of spike by meter rod and then averaged. For biological yield the four central rows from each plot were harvested, weighed and changed to $\mathrm{kg}$ $\mathrm{ha}^{-1}$ by formula.

Biological yield $=$ Biological yield $(\mathrm{kg}) \times 10000$ $\mathrm{R}$ - R distance $\mathrm{x}$ Row length $(\mathrm{m}) \mathrm{x}$ No. of rows Harvest index was calculated for each plot by dividing grain yield on biological yield and then multiplied with 100 to get harvest index in percentage (\%).

Harvest index $(\%)=$ Grain yield $(\mathrm{kg}) \times 100$ Biological yield

\section{Statistical analysis}

Data collected were statistically analyzed according to the method relevant to RCBD. In case of significant F-value, least significance difference (LSD) test was used for mean means comparisons of treatments [14].

\section{Results}

\section{Emergence $\mathbf{m}^{-2}$}

Data analysis showed that different plant water extracts, concentrations and control vs rest significantly affected emergence $\mathrm{m}^{-2}$ while the interaction between extract and concentration was found non-significant (Table 1). Among extracts maximum emergence $\left(89 \mathrm{~m}^{-2}\right)$ were found in plots treated with Sorghum halepense water extract which was statistically at par $\left(85 \mathrm{~m}^{-2}\right)$ with plots treated with Parthenium hysterophorus extract while lower emergence $\left(81 \mathrm{~m}^{-2}\right)$ was recorded in plots treated with water extract of Lantana camara which was statistically similar (83 $\mathrm{m}^{-2}$ ) with Eucalyptus camaldulensis. The mean values for concentration $(\mathrm{C})$ indicated that higher emergence $\left(90 \mathrm{~m}^{-2}\right)$ was recorded in 1:6 concentration while lesser emergence $\left(79 \mathrm{~m}^{-2}\right)$ were recorded in 1:4. Maximum emergence $\left(85 \mathrm{~m}^{-2}\right)$ was noted in all plots treated with different plant water extracts as compared to control $\left(77 \mathrm{~m}^{-2}\right)$. 
Table 1. Emergence $\mathrm{m}^{-2}$, leaf area tiller-1 $\left(\mathrm{cm}^{2}\right)$ and leaf area index of wheat as affected by plant water extracts and their concentrations

\begin{tabular}{|c|c|c|c|}
\hline Plant Extracts (E) & Emergence $\mathbf{~ m}^{-2}$ & Leaf area tiller-1 & Leaf area index \\
\hline E. camaldulensis & $83 \mathrm{~b}$ & $95.50 \mathrm{c}$ & $2.7 \mathrm{c}$ \\
\hline L. camara & $81 \mathrm{~b}$ & $97.13 \mathrm{bc}$ & $2.8 \mathrm{bc}$ \\
\hline P. hysterophorus & $85 \mathrm{ab}$ & $98.23 \mathrm{ab}$ & $2.9 \mathrm{~b}$ \\
\hline S. halepense & $89 \mathrm{a}$ & $100.54 \mathrm{a}$ & $3.0 \mathrm{a}$ \\
\hline LSD & 5 & 2.40 & 0.11 \\
\hline \multicolumn{4}{|c|}{ Concentration (kg: $\mathrm{L}^{-1}$ water) } \\
\hline $1: 4$ & $79 \mathrm{c}$ & $92.06 \mathrm{c}$ & $2.6 \mathrm{a}$ \\
\hline $1: 5$ & $85 \mathrm{~b}$ & $99.23 \mathrm{~b}$ & $2.9 \mathrm{~b}$ \\
\hline $1: 6$ & $90 \mathrm{a}$ & $102.26 \mathrm{a}$ & $3.1 \mathrm{c}$ \\
\hline LSD & 4 & 2.08 & 0.09 \\
\hline Control & 77 & 77.40 & 2.1 \\
\hline Rest & 85 & 97.85 & 2.8 \\
\hline \multicolumn{4}{|l|}{ Interaction } \\
\hline $\mathrm{E} \times \mathrm{C}$ & Ns & Ns & Ns \\
\hline
\end{tabular}

Mean values of the same group having similar letters are non-significant using LSD test at $\%$ level of probability

Leaf area tiller-1 $\left(\mathrm{cm}^{2}\right)$

Leaf area tiller ${ }^{-1}$ varied significantly by different plant water extracts, their concentrations and control vs rest while the interaction of extract and concentration showed no significant variation (Table 1). Among plant extracts, maximum leaf area tiller $^{-1}\left(100.54 \mathrm{~cm}^{2}\right)$ was measured in plots treated with Sorghum halepense which was statistically at par with Parthenium hysterophorus water extract $\left(98.23 \mathrm{~cm}^{2}\right)$. Minimum leaf area tiller-1 $\left(95.50 \mathrm{~cm}^{2}\right)$ was recorded in plots treated with Eucalyptus camaldulensis water extract which was statistically at par with Lantana camara water extract $\left(97.13 \mathrm{~cm}^{2}\right)$. Mean values for concentrations demonstrated that higher leaf area tiller-1 $\left(102.26 \mathrm{~cm}^{2}\right)$ was recorded at 1:6 concentration while lower leaf area tiller $^{-1}$ $\left(92.06 \mathrm{~cm}^{2}\right)$ was recorded at the concentration of 1:4. In case of planned mean comparison maximum leaf area tiller ${ }^{-1}$ $\left(97.95 \mathrm{~cm}^{2}\right)$ was noted in all plots treated with different plant water extracts whereas control plots resulted in minimum leaf area (77.40 $\left.\mathrm{cm}^{2}\right)$ tiller ${ }^{-1}$.

\section{Leaf area index (LAI)}

A significant difference in LAI was observed by plant water extracts, their concentration and control vs rest while the interaction of extracts and concentration was found non-significant (Table 1). In case of plant water extracts maximum Leaf area index (3.0) was found in plots received the extract of Sorghum halepense. Minimum leaf area index (2.7) was recorded in plots treated with Eucalyptus camaldulensis water extract which was statistically alike with Lantana camara water extract. Higher leaf area index (3.1) was recorded at 1:6 concentration while lower leaf area index (2.6) was recorded at 1:4 concentration Regarding planned mean comparison higher leaf area higher leaf area index (2.8) was recorded in all plots received different plant water extracts as compared to control.

Weeds density $\left(\mathrm{m}^{-2}\right)$

Statistical analysis of the data revealed that different plant water extracts, concentrations and control vs rest significantly affected weed density $\mathrm{m}^{-2}$ in wheat while the interaction of extract and concentration was found non-significant (Table 2). Among 
plant extracts maximum weeds $\left(54 \mathrm{~m}^{-2}\right)$ were found in plots treated with the extract of Eucalyptus camaldulensis. While less number of weeds $\left(43 \mathrm{~m}^{-2}\right)$ was recorded in plots treated with the water extract of Sorghum halepense. The mean values for concentration showed that more number of weeds $\left(62 \mathrm{~m}^{-2}\right)$ were found in 1:6 concentration while more concentrated solution decreased number of weeds and minimum weeds $\left(35 \mathrm{~m}^{-2}\right)$ were found in 1:4. Reduced number of weeds $\left(50 \mathrm{~m}^{-2}\right)$ was noted in treated plots as compared to control $\left(93 \mathrm{~m}^{-2}\right)$.

Table 2. Weed density $\left(\mathrm{m}^{-2}\right)$, fresh and dry weeds biomass $\left(\mathrm{g} \mathrm{m}^{-2}\right)$ in wheat as affected by different plant water extracts and their concentrations

\begin{tabular}{|c|c|c|c|}
\hline Plant Extracts (E) & Weed density $\left(\mathrm{m}^{-1}\right)$ & $\begin{array}{l}\text { Weeds fresh biomass } \\
\left(\mathrm{g} \mathrm{m}^{-2}\right)\end{array}$ & $\begin{array}{l}\text { Weeds dry biomass } \\
\left(\mathrm{g} \mathrm{m}^{-2}\right)\end{array}$ \\
\hline E. camaldulensis & $54 \mathrm{a}$ & $130.40 \mathrm{a}$ & $28.25 \mathrm{a}$ \\
\hline L. camara & $53 \mathrm{~b}$ & $109.53 \mathrm{a}$ & $22.57 \mathrm{a}$ \\
\hline P. hysterophorus & $49 \mathrm{~b}$ & $121.40 \mathrm{a}$ & $24.95 \mathrm{a}$ \\
\hline S. halepense & $43 \mathrm{c}$ & $102.43 \mathrm{~b}$ & $19.90 \mathrm{~b}$ \\
\hline LSD $(0.05)$ & 7 & 20.29 & 3.81 \\
\hline \multicolumn{4}{|c|}{ Concentration (kg: $\mathrm{L}^{-1}$ water) } \\
\hline $1: 4$ & $35 \mathrm{c}$ & $74.6 \mathrm{c}$ & $15.8 \mathrm{c}$ \\
\hline $1: 5$ & $51 \mathrm{~b}$ & $120.8 \mathrm{~b}$ & $25.2 \mathrm{~b}$ \\
\hline $1: 6$ & $62 \mathrm{a}$ & $152.5 \mathrm{a}$ & $310.7 \mathrm{a}$ \\
\hline $\operatorname{LSD}(0.05)$ & 6 & 17.57 & 3.30 \\
\hline Control & 93 & 289.10 & 58.82 \\
\hline Rest & 50 & 115.94 & 23.92 \\
\hline \multicolumn{4}{|l|}{ Interaction } \\
\hline $\mathrm{E} \times \mathrm{C}$ & ns & ns & Ns \\
\hline
\end{tabular}

Mean values of the same group having similar letters are non-significant using LSD test at $5 \%$ level of probability

\section{Fresh weeds biomass $\left(\mathrm{g} \mathrm{m}^{-2}\right)$}

Data about fresh weeds biomass in wheat crop are given in Table 2. Different plant water extracts, concentrations and control vs rest significantly affected weed fresh biomass $\left(\mathrm{g} \mathrm{m}^{-2}\right)$, whereas the interaction of extract and concentration showed no significant variation. In case of extracts maximum weeds fresh biomass $\left(130.40 \mathrm{~g} \mathrm{~m}^{-}\right.$

$\left.{ }^{2}\right)$ was recorded in plots treated with the water extracts of Eucalyptus camaldulensis which was statistically similar with Lantana camara (109.53 $\mathrm{g} \mathrm{m}^{-2}$ ) and Parthenium hysterophorus $\left(121.43 \mathrm{~g} \mathrm{~m}^{-2}\right.$ ) fresh weeds biomass respectively while lower weeds fresh biomass $\left(102.43 \mathrm{~g} \mathrm{~m}^{-2}\right.$ ) were recorded in plots treated with the extract of Sorghum halepense. In concentration, higher weeds biomass $\left(152.5 \mathrm{~g} \mathrm{~m}^{-2}\right)$ was found at 1:6 concentration while minimum weeds fresh biomass $\left(120.4 \mathrm{~g} \mathrm{~m}^{-2}\right)$ was recorded at 1:4. Minimum weeds fresh biomass $\left(115.9 \mathrm{~g} \mathrm{~m}^{-}\right.$ $\left.{ }^{2}\right)$ was measured in all plots treated with different plant water extracts as compared to control which produced $289.1 \mathrm{~g} \mathrm{~m}^{-2}$ fresh weed biomass.

\section{Dry weeds biomass $\left(\mathrm{g} \mathrm{m}^{-2}\right)$}

A significant variation in dry weed biomass by plant water extract, concentrations and control vs rest was revealed from statistical analysis of the data whereas interaction of extract and was found non-significant (Table 2). Among extracts, maximum dry weed biomass $\left(2.25 \mathrm{~g} \mathrm{~m}^{-2}\right)$ was noticed in plots treated with Eucalyptus camaldulensis water extract which was statistically at par with Lantana camara (22.57 $\left.\mathrm{g}^{\mathrm{m}} \mathrm{m}^{-2}\right)$ and Parthenium hysterophorus (24.95 $\mathrm{g} \mathrm{m}^{-2}$ ) 
while minimum dry biomass $\left(19.90 \mathrm{~g} \mathrm{~m}^{-2}\right)$ of weeds was recorded in plots treated with the extract of Sorghum halepense. Regarding concentrations higher weed dry biomass $\left(31.22 \mathrm{~g} \mathrm{~m}^{-2}\right)$ was recorded at 1:6 concentrations, while the minimum weeds dry biomass $\left(17.63 \mathrm{~g} \mathrm{~m}^{-2}\right)$ was found at 1:4 concentrations. Minimum weeds dry biomass $\left(23.92 \mathrm{~g} \mathrm{~m}^{-2}\right.$ ) was observed in all plots treated with different plant water extracts while minimum dry biomass of weeds $\left(58.82 \mathrm{~g} \mathrm{~m}^{-2}\right)$ was recorded in control plots.

\section{Plant height (cm)}

Data regarding plane height are reported in Table 3. It was indicated that plant height of wheat differed considerably by different plant water extracts, concentrations and control vs rest while the interaction between extract and concentration showed no significant variation in plant height. Regarding plant water extracts maximum plants height $(87.20 \mathrm{~cm})$ was gained by plots treated with Eucalyptus camaldulensis which was statistically similar with the extract of Sorghum halepense $(85.78 \mathrm{~cm})$. Statistically similar and minimum plant height $(82.27 \mathrm{~cm}$ and $83.32 \mathrm{~cm})$ was observed in plots received extracts of Parthenium hysterophorus and Lantana camara respectively. Taller plants (89.03 $\mathrm{cm}$ ) were observed in plots received the concentration at the rate of 1:6 while dwarf plants $(80.36 \mathrm{~cm})$ were produced by plots treated with the concentration of 1:4. In planned mean comparison taller plant height $(84.61 \mathrm{~cm})$ were maintained by all plots treated with different plant water extracts whereas dwarf plants $(80 \mathrm{~cm})$ were recorded in control plots.

Table 3. Plant height (cm), biological yield $\left(\mathrm{kg} \mathrm{ha}^{-1}\right)$ and harvest index (\%) of wheat as affected by plant water extracts and their concentrations

\begin{tabular}{|c|c|c|c|}
\hline Plant extracts $(\mathbf{E})$ & Plant height $(\mathrm{cm})$ & Biological yield $\left(\mathrm{kg} \mathrm{ha}^{-1}\right)$ & Harvest index (\%) \\
\hline E. camaldulensis & $87.20 \mathrm{a}$ & $8207 \mathrm{~b}$ & $34.97 \mathrm{~b}$ \\
\hline L. camara & $83.32 \mathrm{~b}$ & $8231 \mathrm{~b}$ & $37.48 \mathrm{a}$ \\
\hline P. hysterophorus & $82.27 \mathrm{~b}$ & $8413 \mathrm{~b}$ & $37.63 \mathrm{a}$ \\
\hline S. halepense & $85.68 \mathrm{a}$ & $8717 \mathrm{a}$ & $38.34 \mathrm{a}$ \\
\hline LSD & 1.89 & 285 & 2.03 \\
\hline \multicolumn{4}{|c|}{ Concentration (kg: $\mathbf{L}^{-1}$ water) } \\
\hline $1: 4$ & $80.36 \mathrm{c}$ & $7816 \mathrm{c}$ & $35.81 \mathrm{~b}$ \\
\hline $1: 5$ & $84.46 \mathrm{~b}$ & $8289 \mathrm{~b}$ & $37.19 \mathrm{a}$ \\
\hline $1: 6$ & $89.03 \mathrm{a}$ & $9071 \mathrm{a}$ & $38.31 \mathrm{a}$ \\
\hline LSD & 1.63 & 247 & 1.75 \\
\hline Control & 80.00 & 6586 & 30.69 \\
\hline Rest & 84.61 & 8392 & 37.11 \\
\hline \multicolumn{4}{|l|}{ Interaction } \\
\hline $\mathrm{E} \times \mathrm{C}$ & ns & Ns & ns \\
\hline
\end{tabular}

Mean values of the same group having similar letters are non-significant using LSD test at $5 \%$ level of probability

Biological weight $\left(\mathrm{kg} \mathrm{ha}^{-1}\right)$

Different plant water extracts, concentrations and control vs rest significantly affected biological yield of wheat while the interaction between extract and concentration did not show any significant difference (Table 3). Among plant water extracts maximum biological yield $\left(8717 \mathrm{~kg} \mathrm{ha}^{-1}\right)$ was produced by plots sprayed with the extract of Sorghum halepense while minimum biological yield $\left(8207 \mathrm{~kg} \mathrm{ha}^{-1}\right)$ was recorded in plots treated 
with the extract of Eucalyptus camaldulensis which was statistically similar with that of Lantana camara and Parthenium hysterophorus water extract treated plots. The mean values for concentration showed that maximum biological yield $\left(9071 \mathrm{~kg} \mathrm{ha}^{-}\right.$ $\left.{ }^{1}\right)$ was noted at 1:6 concentration while minimum biological yield $\left(7816 \mathrm{~kg} \mathrm{ha}^{-1}\right)$ was recorded at concentration of 1:4. In planned mean comparison, control plots gave minimum biological yield $(6585 \mathrm{~kg}$ ha $\left.{ }^{1}\right)$ whereas maximum biological yield (8392 $\mathrm{kg} \mathrm{ha}^{-1}$ ) was recorded in all plots received the extracts of different plants.

\section{Harvest index (\%)}

The significant response of water extracts of different plants at various concentrations and control vs rest on harvest index of wheat is reported in Table 3. The interaction between extracts and concentrations did not show any significant response on harvest index of wheat. Among plant water extracts maximum harvest index $(38.34 \%)$ was recorded in plots treated with the extract Sorghum halepense which was statistically similar with that of Parthenium hysterophorus and Lantana camara treated plots. Minimum harvest index (34.97 \%) was noticed in plots sprayed with the water extract of Eucalyptus camaldulensis. Maximum harvest index (38.31\%) was resulted at 1:6 concentration which was statistically similar with $1: 5$ while minimum harvest index $(35.81 \%)$ was recorded at concentration of 1:4. In planned mean comparison maximum harvest index (37.11 $\%$ ) was recorded in all plots treated with different plant water extracts as compared to control plots in which minimum harvest index $(30.69 \%)$ was recorded.

\section{Discussion}

Different plant water extracts and their concentrations significantly affected emergence $\mathrm{m}^{-2}$ of wheat. This might be due to the high level of allelochemicals which was toxic to wheat seedlings and hence inhibited their growth. Our results are supported by Shahid et al. [9] who explained that the inhibiting effect of sunflower allelopathy on seed germination appeared to be mediated during cellular disruption of metabolism rather than through organelle injury. The reserved mobilization might have been stopped or delayed during allelopathic stress consequently reduced the seed germination. Such results were also obtained by Bogatek et al. [15]. Leaf area tiller $^{-1}$ considerably differed by the application of different plant water extracts used in various concentrations. This might be due to the fact that higher concentration of plant water extracts has inhibitory effect while lower concentration has stimulatory effect. The maximum leaf area tiller ${ }^{1}$ obtained might be due to fewer weed density and hence less competition for food resources between weeds and crop. Thus crop got chance to survive freely and maximum leaf area was formed. Same results were recorded by Cheema et al. [16] who explained that sorghum water extract treated plot resulted maximum leaf area. Our observations are also supported by Elahi et al. [17] who stated that plant grow higher and produced enlarged leaf area tiller ${ }^{-1}$ due to the suppression of weeds. A significant increase in LAI was observed by the application of plant water extracts and their concentration. The increased in LAI might be due to larger leaf area tiller ${ }^{-1}$ and more number of tillers $\mathrm{m}^{-2}$. These findings are harmonious with [18] who reported that different plant water extract increased LAI. $[19,20]$ also noticed increased leaf area index when sorghum water extract was applied in optimum concentration.

Statistical analysis of the data revealed that the concentrations of different plant water extracts reduced weed density in wheat. These results are also in line with [21, 22] who proved that more inhibitory effect was caused by high concentration. Similarly, 
weeds density was suppressed with inhibitory effect of increased extract concentration of phenolic compounds [23, 24]. Weeds were suppressed by application of different plant water extracts resulting low weeds density and hence low fresh weeds biomass. The possible reason might be the presence of allelopathic compound in the plant extracts. More fresh weeds biomass was calculated in control plots as compared to plots treated with plant water extracts. [25] also stated that more weeds fresh biomass was noticed in control plots while minimum weeds fresh biomass was in plots sprayed with Phragmites australs water extract. These findings are in line with Rab et al. [20] and Khan [22] who reported maximum fresh weeds weight at lower extract concentration and minimum fresh weed weight at higher extract concentration. Similar reduction was also observed in dry weight of weeds by the application water extracts of different plant in various concentrations. Our results were also supported by Rab et al. [20] and Khan [22] who found reduction in weed dry weight at higher concentration of plant water extract. Our findings are further supported by Awan et al. [26] and Arif et al. [27] who noticed remarkable decrease in weeds dry biomass with different plant water extracts.

Plant height of wheat differed considerably by the concentrations of different plant's water extracts. This might be due to the fact that high concentration of plant water extract has suppressive effect on plant height. Our observations are supported by Shahid et al. [9] who stated that different plant water extracts exhibited suppressive effects on height of wheat crop. [28] also proved the toxic effect of allelochemicals on shoot length. Different plant water extracts and concentrations significantly affected biological yield of wheat. Maximum biological yield might be due to potential of controlling weeds by different plant water extracts. Our arguments are in line with [29] who verified that increase in biological yield is due to spray of plant water extracts. The results are also confirmed by Awan et al. [26] and Khan et al. [30] who proved that maximum biological yield was resulted by spray of sunflower and sorghum water extract at different days after sowing. Improved biological yield was also reported by Shahid et al. [9], Rab et al. [20] and Khan [22] by the application of natural herbicides. Harvest index of wheat increased by the application of water extracts of different plants at various concentrations. Higher harvest index might due to better weeds control which enabled wheat to receive more nutrients. Our findings are in relation with $[16,18,22,26,31]$ who noted remarkably enhanced harvest index of wheat crop over control by the application of different plant water extracts.

\section{Conclusion}

The authors were arrived at conclusion that Sorghum halepense water extract when applied at concentration 1:6 imparted better results in terms of wheat biomass and suppressing weeds as compared to control.

\section{Authors' contributions}

Conceived and designed the experiments: S Anwar \& A Hussain, Performed the experiments: A Hussain \& S Anwar, Data collection and field inspections A Hussain, M Islam \& Ikramullah, Statistical Analysis of the data: M Islam, Z Hussain, Ikramullah \& N Khan, Contributed reagents/ materials/ analysis tools: Z Hussain, S Anwar \& M N Shoaib, Wrote the paper: A Hussain \& M Islam

\section{References}

1. Khalil IA \& Jan A (2005). Cropping Tectnonolgy, National Book Foundation Islamabad, Pakistan.14: 170-171.

2. MNFSR (2014). Ministry of National Food Security and Research, Agricultural Statistics, Economic Wing, Government of Pakistan, Islamabad. 
3. Jabran K, Cheema ZA, Farooq M \& Khan MB (2011). Fertigation and foliar application of fertilizers alone and in combination with canola extracts enhances yield in wheat crop. Crop Environ 2(1): 42-45.

4. Farooq M, Jabran K, Cheema ZA, Wahid A \& Siddique KHM (2011). The role of allelopathy in agricultural pest management. Pest Manage Sci 67(5): 493-506.

5. Bhadoria BPS (2011). Allelopathy: a natural way towards weed management. American J of Exp Agri 1(1): 7-20.

6. Bhowmik PC \& Inderjit J (2003). Challenges and opportunities in implementing allelopathy for natural weed management. Crop Prot 22(4): 661671.

7. Tefera T (2002). Allelopathic effects of Parthenium hysterophorus extracts on seed germination and seedling growth of Eragrostis tef. J Agron Crop Sci 188 306310.

8. Moradshahi A, Ghadiri H \& Ebrahimikia F (2003). Allelopathic effects of crude volatile oil and aqueous extracts of Eucalyptus camaldulensis Dehnh. leaves on crops and weeds. Allelopathy J 12(2): 189-195.

9. Shahid M, Ahmad B, Khatak RA, Hassan G \& H Khan (2006). Response of wheat and its weed to different plant water extracts. Proc. $2^{\text {nd }}$ International weed Sci. Conf., March 20-22 Rawalpindi Paksiatan p.7.

10. Bansal GL (1998). Allelopathic effects of Lantana camara on rice and associated weeds under the midhill conditions of Himachal Pradesh, India. In M. Olofsdotter (ed.), Proc. Workshop on Allelopathy in Rice, Manila (Philippines): Int Rice Res Inst 133-138.

11. Oudhia P \& Tripathi RS (1999). Allelopathic effect of Lantana camara L. on rice, Agri Sci Dig 19: 43-45.
12. Majeed M, Abdul M, Chaudhry Z \& Muhammad Z (2012). Allelopathic assessment of aqueous extract of Chenopodium album L. for growth and yield of wheat (Triticum sativum L.). Pak J Bot 44(1): 165-167.

13. Khalil SK, Zeb K \& Khan AZ (2002). Changes in leaf area assimilate accumulation and partitioning of wheat varieties planted on different dates. Pak J Soil Sci 21: 15-19.

14. Jan MT, Shah P, Hollington PA, Khan MJ \& Sohail Q (2009). Agriculture Research: Design and Analysis, A Monogragh. NWFP Agric Univ Pesh Pak.

15. Bogatek R, Gniazdowska A, Zakrzewska W, Oracz K \& Gawronski SW (2006). Allelopathic effects of sunflower extracts on mustard seed germination and seedling growth. 50(1): 156-158.

16. Cheema ZA, Iqbal $M$ \& Ahmad $R$ (2002). Response of wheat varieties and some Rabi weeds to allelopathic effects of sorghum water extract. Int J Agri Biol 4(1): 52-55.

17. Elahi M, Cheema ZA, Basra SMA, Akram M \& Ali Q (2011). Use of allelopathic water extract of field crops for weed control in wheat. Int Res $J$ Plant Sci 2(9): 262-270.

18. Jamil M, Cheema ZA, Mushtaq MN, Farooq M \& Cheema MA (2009). Alternative control of wild oat and canary grass in wheat fields by allelopathic plant water extracts. Agron. Sustain Dev 29: 475-482.

19. Khaliq A, Matloob A, Khan MB \& Tanveer A (2013). Differential suppression by rice weeds by allelopathic plant aqueous extracts. Planta Daninha 31(1): 21-28.

20. Rab A, Khalil SK, Asim M, Khan I, Fayyaz H, Raza H, Khan MR, Zahid H \& Khan F (2016). Impact of sorghum 
extract type, concentration and application time on weedsdensity and wheat yield. Pak J Weed Sci Res 22(3): 425-439.

21. Jafri L, Ghadiri H \& Moradshahi A (2011). Allelopathic Potential of Rice Cultivarson Banyard Grass. J Agri Sci Ttech 1: 853-864.

22. Khan I (2016). Effect of rice herbage type, concentration and application time on weeds density and yield of wheat. $\mathrm{M}$. Sc (Hons) thesis, Dept. of Agron. The Uni of Agric Peshawar-Pakistan

23. Hall AB, Blum U \& Fites RC (1982). Stress modification of allelopathy of Helianthus annuus L. debris on seedling. J Bot 69: 776-783.

24. Naseem M (1997). Allelopathic effects of autumn sunflower residues on wheat productivity and wheat-weeds. PhD thesis. Department of Agronomy. University of Agriculture, FaisalabadPakistan

25. Khan MB, Ahmad M, Hussain M, Jabran K, Farooq $S$ \& Waqas HM (2012). Allelopathic plant water extracts tank mixed with reduced doses of atrazine efficiently control Trianthema portulacastrum L. in Zea mays L. The J Anim Plant Sci 22(2): 339-346.
26. Awan FK, Rasheed M, Ashraf M \& Khurshid MY (2012). Efficacy of brassica, sorghum and sunflower aqueous extracts to control wheat weeds under rainfed conditions of Pothwar. Pak J Anim Pl Sci (22): 715-721.

27. Arif M, Cheema ZA, Khaliq A \& Hassan A (2015). Organic weed management in wheat through allelopathy. Int J Agric Biol 17(1): 127134.

28. Anjum T, Bajwa R \& Javaid A (2005). Effect of Imperata cylindrica on distribution, germination and seedling growth of Parthenium hysterophorus L. Int J Agric Biol 7(3): 448-450.

29. Cheema ZA \& Khaliq A (2000). Use of sorghum allelopathic properties to control weeds in irrigated wheat in a semi-arid region of Punjab. Agric Eco Environ 79: 105-112.

30. Khan EA, Khakhwani AZ, Munir M \& Ullah G (2015). Effect of allelopathic chemicals extracted from various plant leaves on weed control and wheat crop productivity. Pak J Bot 47(2). 735-740.

31. Marwat KB, Hussain Z, Saeed A, Gul B \& Noor S (2005). Chemical weed management in wheat at higher altitudes. Pakistan. J Weed Sci Res 11: 102-107. 